\title{
Formation of future teachers' meta-competence as a base to develop their potential readiness for continuing education
}

\author{
Formação da meta-competência dos futuros professores como base \\ para desenvolver sua prontidão potencial para a educação continuada
}

\section{Formación de la metacompetencia de los futuros docentes como base para desarrollar su potencial preparación para la educación continua}

Veronika M. Grebennikova ${ }^{1}$ iD , Victoria A. Kazantseva ${ }^{1}$ (D), Angelica V. Karpenko ${ }^{1}$ (D), ]Andrey N. Krishtopa ${ }^{1}$ iD , Oksana A. Us ${ }^{1}$ iD, Ilya N. Tuzov²

\footnotetext{
${ }^{1}$ Kuban State University, Krasnodar, Russia.

${ }^{2}$ Academy of Social Management, Mytischi, Moscow region, Russia.
}

Corresponding author:

Veronika M. Grebennikova

Email: v.m.grebennikova@bk.ru

How to cite: Grebennikova, V. M., Kazantseva, V. A., Karpenko, A. N., Krishtopa, A. N., Us, O. A., \& Tuzov, I. N. (2021). Formation of Future Teachers' Meta-Competence as a Base to Develop Their Potential Readiness for Continuing Education. Revista Tempos e Espaços em Educação, 14(33), e16573. http://dx.doi.org/10.20952/revtee.v14i33.16573

\section{ABSTRACT}

The purpose of the study is to identify the features of the relationship between the potential readiness of future teachers for lifelong education and the level of development of metacompetence and to develop recommendations on this basis for creating conditions in the university for the development of students' meta-cognitive abilities. Research methods and materials. The study involved 748 students enrolled in teacher education programs. Studied: the level of formation of future teachers of psychological, strategic and competence-based readiness for lifelong education (questionnaire survey); the level of development of their worldview ("Methodology of worldview activity" by D.A. Leontyev, A.N. Ilchenko), intellectual ("Mental performance and the type of intelligence" by B.N. Ryzhov), cognitive ("Methodology for assessing the systemic nature of thinking" I.A. Sychev) and operational-procedural (methods for identifying the level of formation of mental operations (methods for identifying the ability to analyze, compare, generalize and classify) components of metacompetence. Comparative (chi-square test, Student's t-test) and correlation (Spearman's correlation coefficient ) analyzes. Results. A close relationship was revealed between the indicators of the potential readiness of future teachers for lifelong pedagogical education and individual components of metacompetence, characteristics of students' worldview, their intelligence and cognitive abilities. Conclusion. The results of the study suggest that the formation of future teachers' readiness for lifelong education should be based not only and not so much on 
stimulating their motivational activity, but also on creating conditions for the development of their worldview, intelligence, systemic, creative thinking and general cognitive abilities.

Keywords: Continuing education. Future teachers. Meta-competence. Multi-disciplinary context. Integrative technologies.

\section{RESUMO}

O objetivo do estudo é identificar as características da relação entre a potencial preparação dos futuros professores para a educação ao longo da vida e o nível de desenvolvimento da metacompetência e desenvolver recomendações nesta base para criar condições na universidade para o desenvolvimento dos alunos. 'habilidades meta-cognitivas. Métodos e materiais de pesquisa. 0 estudo envolveu 748 alunos matriculados em programas de formação de professores. Estudados: 0 nível de formação dos futuros professores de prontidão psicológica, estratégica e baseada nas competências para a educação ao longo da vida (inquérito por questionário); o nível de desenvolvimento de sua visão de mundo ("Metodologia da atividade de visão de mundo" por DA Leontyev, AN Ilchenko), intelectual ("Desempenho mental e o tipo de inteligência" por BN Ryzhov), cognitivo ("Metodologia para avaliar a natureza sistêmica do pensamento" IA Sychev) e operacionalprocedimental (métodos para identificar o nível de formação das operações mentais (métodos para identificar a capacidade de analisar, comparar, generalizar e classificar) componentes de metacompetência. Comparativos (teste qui-quadrado, teste t de Student) e análises de correlação (coeficiente de correlação de Spearman). Resultados. Uma estreita relação foi revelada entre os indicadores de prontidão potencial dos futuros professores para a educação pedagógica ao longo da vida e os componentes individuais da metacompetência, características da visão de mundo dos alunos, sua inteligência e habilidades cognitivas. Conclusão. Os resultados do estudo sugerem que a formação da prontidão dos futuros professores para a formação ao longo da vida deve basear-se não só e não tanto no estímulo à sua atividade motivacional, mas também na criação de condições para o desenvolvimento da sua visão de mundo, inteligência, pensamento sistémico, criativo e habilidades cognitivas gerais.

Palavras-chave: Educação continuada. Futuros professores. Meta-competência. Contexto multidisciplinar. Tecnologias integrativas.

\section{RESUMEN}

El propósito del estudio es identificar las características de la relación entre la preparación potencial de los futuros docentes para la educación permanente y el nivel de desarrollo de la metacompetencia y desarrollar recomendaciones sobre esta base para crear las condiciones en la universidad para el desarrollo de los estudiantes. 'habilidades metacognitivas. Métodos y materiales de investigación. El estudio involucró a 748 estudiantes inscritos en programas de formación docente. Estudiado: el nivel de formación de los futuros profesores de preparación psicológica, estratégica y por competencias para la educación permanente (encuesta por cuestionario); el nivel de desarrollo de su cosmovisión ("Metodología de la actividad de cosmovisión" por DA Leontyev, AN Ilchenko), intelectual ("Rendimiento mental y el tipo de inteligencia" por BN Ryzhov), cognitivo ("Metodología para evaluar la naturaleza sistémica del pensamiento" IA Sychev) y operacionalprocedimental (métodos para identificar el nivel de formación de operaciones mentales (métodos para identificar la capacidad de analizar, comparar, generalizar y clasificar) componentes de la metacompetencia. Comparativo (prueba chi-cuadrado, prueba $t$ de Student) y análisis de correlación (coeficiente de correlación de Spearman). Resultados. Se reveló una estrecha relación entre los indicadores de la preparación potencial de los futuros profesores para la educación pedagógica permanente y los componentes individuales de la metacompetencia, las características de la cosmovisión de los estudiantes, su inteligencia y habilidades cognitivas. Conclusión. Los resultados del estudio sugieren que la formación de la preparación de los futuros docentes para la 
educación permanente debe basarse no solo y no tanto en estimular su actividad motivacional, sino también en crear las condiciones para el desarrollo de su cosmovisión, inteligencia, pensamiento sistémico, creativo y habilidades cognitivas generales.

Palabras clave: Educación continua. Futuros profesores. Metacompetencia. Contexto multidisciplinario. Tecnologías integradoras.

\section{INTRODUCTION}

\section{Problem Definition}

One of the most promising possibilities for improving Higher Teacher Education is working out ways and conditions to form future teachers' readiness for the achievement of personal fulfillment in their chosen fields of expertise, to form their readiness and ability for selfdevelopment and education not for the rest of their professional career as teachers, but throughout their life. At present, the idea of continuing education originated in the works of classic teachers, is being put into practice through the implementation and introduction of new pedagogical forms and technologies (Grebennikova \& Uzunova, 2020).

A modern teacher is not only a person who has received a high-quality higher education, but also a specialist who strives for professional growth independently choosing ways and means of improving qualifications and is capable of continuous self-education, self-development, and selfimprovement (Alekseeva, 2018).

The essence of continuing education is to consider it a particular way of life of a person, eager to embrace new ideas, as a self-organized cognitive activity aiming to achieve high professional results by updating, replenishing, deepening knowledge, and enhancing professional skills and professional competency.

Pointing towards the vital role of continuous teacher education, the researchers note that not every teacher is ready to implement it and to continue learning throughout his life (Grebennikova \& Uzunova, 2020; Raspopova et al., 2018).

In this regard, the formation of teachers' readiness for continuing education, the search for effective ways and means to increase the activity of teachers in independent cognitive activity have been mainstreamed (Ivanova, 2018; Ivanova et al., 2015; Strelkov et al., 2016; Penkova et al., 2018). Teacher's meta-competence is considered as a basis for the development of such readiness.

\section{The Nature and Structure of Meta-competence}

The theoretical analysis results indicate that the concept of "meta-competence" can be interpreted differently, encompassing a wide range of different meanings and senses. However, the term "meta-competence" itself belongs to the basic concepts of the meta-disciplinary approach, recognized by the Federal Educational Standards as the main methodological principle of the educational process within the framework of basic general education (Karpov \& Demidova, 2013). Implementing the meta-disciplinary approach is focused mainly on school education, with metadisciplinary competencies associated with universal learning skills.

A small number of works carried out in recent years are dedicated to the issues of the development of meta-competence in students as future professionals (Osipov, 2019). Basically, these are researches on developing meta-competence in students through teaching specific academic disciplines (Krishtopa, 2020).

The definition of the characteristics of meta-competence leads to the fact that it is essential to consider the concepts of "general cultural competence" and "universal competences," as one of the final results of the national higher education refers to a high level of development of these competencies (Tarkhanova, 2018; Kazakova \& Tarkhanova, 2018). Under universal competencies a wide range of issues is understood. As a citizen of his country and as a subject of labor, the future specialist should be well informed about such issues as well as have up-to-date knowledge and 
experience of activities (Tarkhanova, 2019). According to researchers, general cultural competence and universal competencies are interconnected with the value structure of the future specialist's personality, ability to perceive the world around him/her adequately, understand his/her purpose, and his/her role in social development (Ivanova, 2018). According to some researchers, general cultural or universal competencies include, among other things, competencies that enable students to become complete subjects of the educational process, which involves the development of their cognitive culture, and the ability to perceive the theoretical and practical teaching material adequately (Tarkhanova, 2019; Bonkalo et al., 2021). In teaching, these competencies are called meta-competencies, which in its general form means the culture of cognitive activity (Shabanov, 2015).

According to A.V. Khutorskoy, the meta-disciplinary essence of modern education is that the interaction of external and internal in a person, his/her macro-and microcosm is carried out through activities that reflect the nodal, fundamental foundations of the world and humanity. Metadisciplinary education results are reflected in forming a whole range of universal competencies or meta-competencies (Khutorskoy, 2013).

In the new Federal State Education Standards of Higher Education (FSES HE), the universal competencies are united into major groups, representing the university's generalized result of professional training. Reaching the bachelor's level is demonstrated by the formation of the following modules of universal competences formation:

-Man and Society (safe environment, legal area, difference in cultural values, social interaction, historical processes);

-Man and Science (abstract knowledge, critical thinking, scientific mindset, scientific methods of searching and processing information, scientific methods of cognition);

-Man in Digital Space (multimedia objects, social services, search engines, e-learning, searching for specific information skills) (Belkina \& Makeeva, 2018). As we see, the second group, Man and Science, implies the formation of future bachelors' meta-competencies, reflecting their ability and readiness to acquire the necessary knowledge independently (Fedotova \& Starostina, 2018).

Therefore, the theoretical analysis results allow defining the meta-competence of future bachelors of teaching as a particular form of their personality, reflecting their ability and readiness to independently acquire new knowledge and learn and carry out educational-cognitive and educational-research activities (Karpov \& Demidova, 2013).

Meta-competence implies that future teachers have general cultural literacy, education, and meta-competencies that reflect certain aspects of the meta-competence as holistic education. Meta-competence, in essence, is associated with the cognitive abilities of students (Karpov \& Demidova, 2013), with the development of their intelligence (Ryzhov, 2010), and features of their cognitive styles (Kholodnaya, 2004).

In the structure of meta-competence, one can distinguish worldview (scientific worldview and research position), intellectual (general characteristics of intelligence), cognitive (system thinking, particularities of thinking), and operational and procedural (level of proficiency in thinking) components.

This definition was the basis for the research, the purpose of which was to identify the features of the relationship between the potential readiness of future teachers for continuing education and the level of development of meta-competence and to develop on this basis recommendations for creating conditions in the university for the development of meta-cognitive skills of students. 


\section{RESOURCES AND METHODOLOGY}

The research was conducted based on Universities in the Krasnodar krai of the Russian Federation implementing Programs of Higher Pedagogical Education. A total of 748 graduate students enrolled in the relevant training areas participated in the study. The diagnostic tools of the research are the author's questionnaire to identify students' readiness for continuing education, Methodology of Worldview Activity, Mental Performance and Type of Intelligence (Ryzhov, 2010), methods to identify the level of formation of thinking operations (Comparison of Concepts comparison and generalization operations; Proverbs Interpretation - abstraction operations; Selection of Essential Features - generalization and classification; Complex Analogies - ability to identify complex logical connections), Evaluation Method of Thinking System (Sychev, 2009).

Based on the research of the level of future teachers' readiness for continuing education, two groups were formed from the total research sample; a group of students with a high level of potential readiness for continuing education $(n=172)$, and a group consisting of students with a low level of indicated readiness $(n=172)$.

A comparative analysis of average group indicators of features and the level of metacompetence development (t-Student's Test) was conducted in two groups. Correlation analysis of empirical data (Spearman's rank correlation coefficient) was carried out on the total sample.

\section{RESULTS}

\section{The Level of Readiness of Future Teachers for Continuing Education}

A survey revealed that only $22,99 \%$ are characterized by a high level of readiness for continuing education; $24,20 \%$ have a low level, and $52,81 \%$ have an average level. Meanwhile, the demand for continuing education is not high enough. In most cases, the need for lifelong learning is perceived by future teachers as a need rather than an intrinsic necessity. The will of students prevails over the position of desire.

Thus, students' interest in continuing education is quite low. Their motivation to acquire allnew pedagogical knowledge is not quite clear and is not distinguished by an intrinsic need for knowledge and self-education.

Moreover, the analysis of indicators of individual components of readiness for continuing education, namely, psychological (desire, motives, interest), strategic (courses, programs), and competence (conscious goals, internal cognitive need), showed that in general modern students understand the need for continuing education for teachers. Still, the intrinsic need for independent acquisition of additional professional knowledge and skills is not experienced (Figure 1).

Figure 1. Percentage of future teachers by level of readiness for continuing education $(n=748, \%)$.

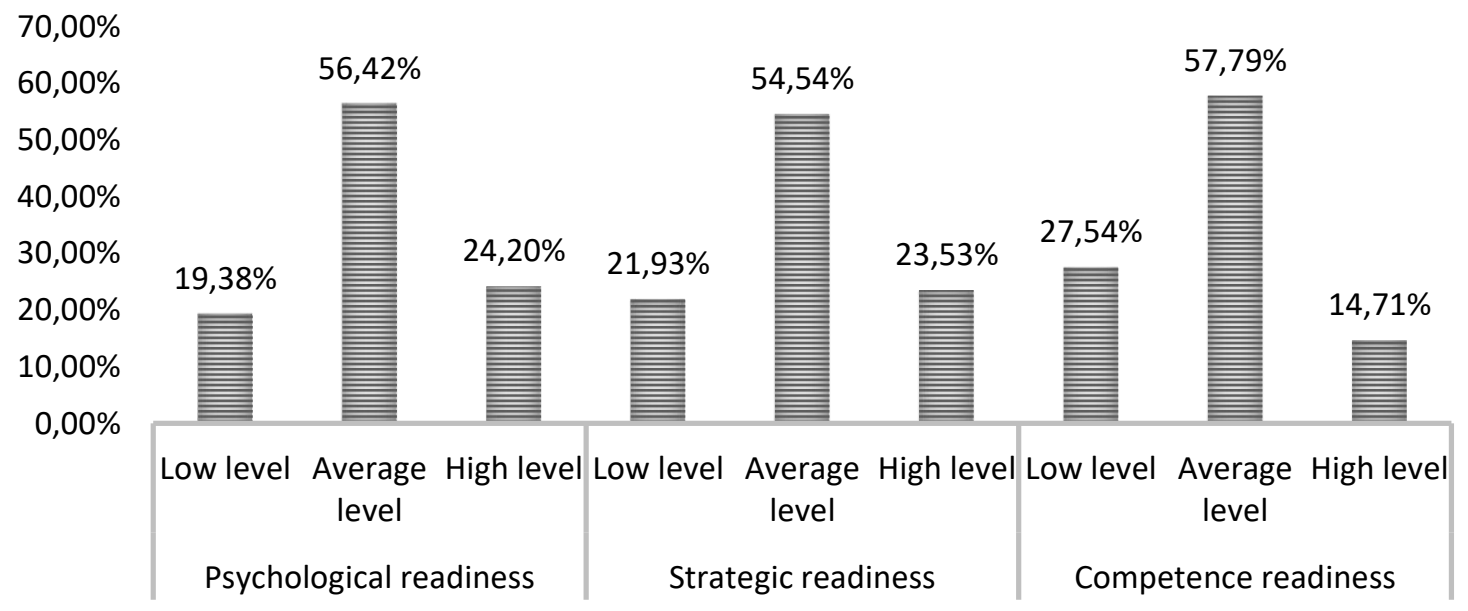


Thus, only $14,71 \%$ of future teachers are characterized by a high level of development of competence readiness for continuing education, implying their adequate understanding of not only the need to continue acquiring knowledge independently but also the intrinsic need for selfdevelopment and self-actualization in the selected field of professional and teaching activity.

\section{Peculiarities of Future Teachers' Meta-Competence Development}

Based on the theoretical analysis results, we have assumed that the readiness of future teachers for continuing education is determined by the level and peculiarities of their metacompetence development.

This hypothesis was verified in two ways.

The comparative analysis of the indicators of each component of meta-competence revealed significant differences between the contrasting groups of students: students characterized by high and, correspondingly, low levels of readiness for continuing education (Table 1).

Statistically significant differences between the two study groups were found for such indicators as "worldview one-dimensionalism" ( $t=5,1242 ; p<0,001)$ and "worldview initiativity" ( $t$ $=5,8765 ; p<0,001)$.

Table 1. Results of a comparative analysis of meta-competence indicators in the two research groups.

\begin{tabular}{|c|c|c|c|c|}
\hline $\begin{array}{l}\text { Indicators } \\
\text { (questionnaire scales) }\end{array}$ & $\begin{array}{l}\text { High level of } \\
\text { availability }\end{array}$ & Low availability & $\mathrm{t}, \chi^{2}$ & $\mathrm{P}$ \\
\hline \multicolumn{5}{|c|}{ Worldview component of meta competence } \\
\hline World outlook one-dimensionality & $2,36 \pm 0,4$ & $5,94 \pm 0,6$ & 5,1242 & $<0,001$ \\
\hline Worldview multidimensionality & $4,52 \pm 0,5$ & $4,98 \pm 0,6$ & 0,6223 & $>0,05$ \\
\hline World outlook initiative & $7,38 \pm 0,7$ & $2,62 \pm 0,4$ & 5,8765 & $<0,001$ \\
\hline \multicolumn{5}{|c|}{ Intelligent component of meta-competence } \\
\hline The pace of mental activity & $5,68 \pm 0,6$ & $6,09 \pm 0,6$ & 0,4472 & $>0,05$ \\
\hline The breadth of the mind & $7,34 \pm 0,8$ & $4,00 \pm 0,5$ & 3,5532 & $<0,01$ \\
\hline Depth of mind & $5,32 \pm 0,6$ & $3,26 \pm 0,5$ & 2,6410 & $<0,05$ \\
\hline \multicolumn{5}{|c|}{ The cognitive component of meta competence } \\
\hline Pre-system level & $0,00 \%$ & $16,86 \%$ & & \\
\hline Empirical-systemic level & $8,14 \%$ & $57,56 \%$ & 484,48 & $<0,001$ \\
\hline Integrative system level & $81,98 \%$ & $25,58 \%$ & & \\
\hline Structural and system level & $9,88 \%$ & $0,00 \%$ & & \\
\hline \multicolumn{5}{|c|}{ Operational and procedural component of meta-competence } \\
\hline Analysis & $8,24 \pm 0,8$ & $5,36 \pm 0,6$ & 2,8000 & $<0,01$ \\
\hline Comparison & $8,62 \pm 0,9$ & $5,59 \pm 0,6$ & 2,6481 & $<0,05$ \\
\hline Generalization & $7,98 \pm 0,8$ & $5,26 \pm 0,5$ & 2,9361 & $<0,01$ \\
\hline Classification & $6,92 \pm 0,7$ & $4,42 \pm 0,5$ & 2,9651 & $<0,01$ \\
\hline Abstraction & $7,56 \pm 0,8$ & $4,99 \pm 0,6$ & 2,4600 & $<0,05$ \\
\hline
\end{tabular}

Students with a high level of readiness for continuing education, to a greater extent than those characterized by a lack of readiness for self-development and self-education throughout life, are prone to worldview activity, strive for change, and make sense of life and professional activities.

Most of these students are tolerant of uncertainty, flexible in their aspirations, and need to know the world in all its diversity.

It is noteworthy that the group average indicators of the level of proficiency in thinking operations are significantly higher in the group of students with the developed ability to selforganized cognitive activity than in the other group of students: The majority of students in the first group have a high level of proficiency in the operations of analysis $(t=2,800, p<0,01)$, comparison $(t=2,6481, p<0,05)$, generalization $(t=2800, p<0,001)$, classification $(t=2,9651, p<0,01)$ and abstraction $(t=2,4600, p<0,01)$. 


\section{The Relationship between Indicators of Readiness for Continuing Education and the Peculiarities of Meta-Competence Development}

The results of correlation analysis confirmed the empirical hypothesis. There is a close, reliable relationship between the willingness of future teachers for continuing education and the level of development of meta-competence (Figure 2).

Figure 2. Correlations between the indicators of future teachers' readiness for continuing education and the peculiarities of meta-competence development.

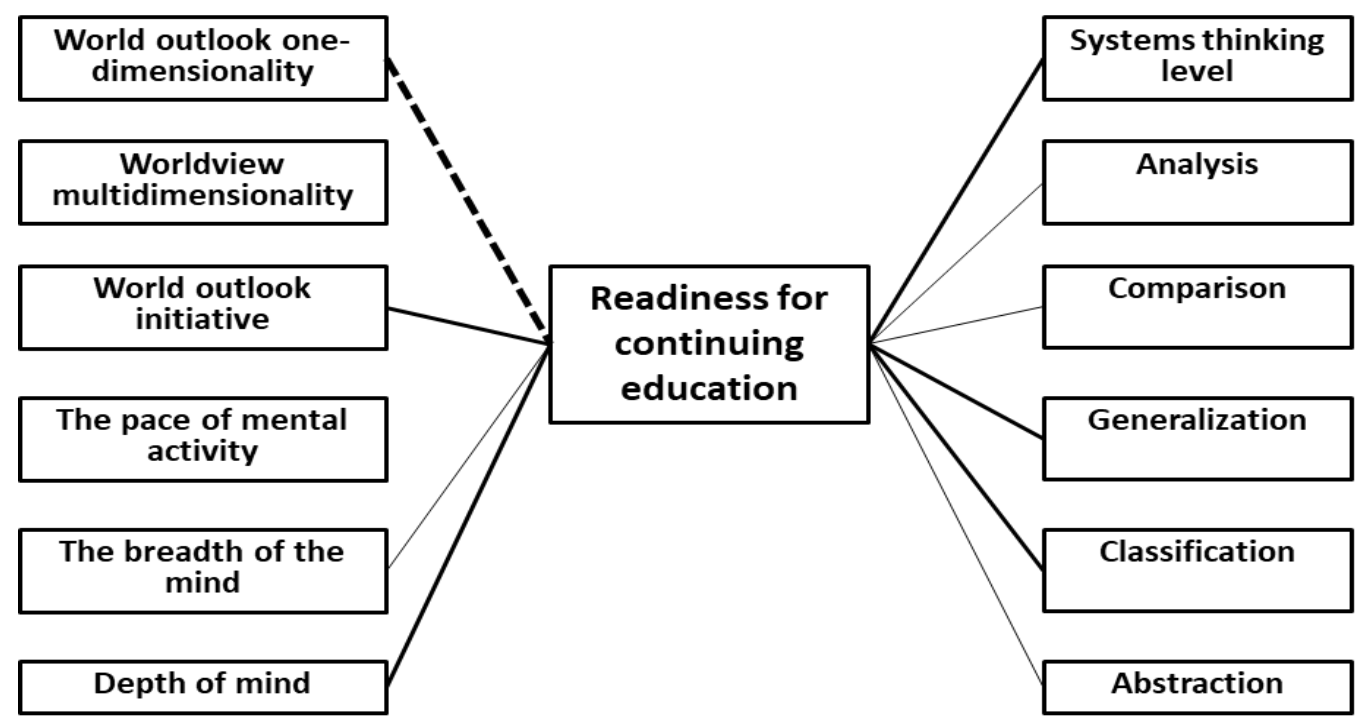

According to the results of the correlation analysis performed on the total research sample, it can be said that the higher the level of potential readiness of future teachers for continuing education, the higher their worldview activity $(r=0,4543 ; p<0,001)$, broadness $(r=0,1964 ; p<$ $0,05)$ and profoundness $(r=0,3396 ; p<0,001)$ of thinking activities, systematic thinking $(r=0,3842$; $p<0,001)$ and their level of proficiency in thinking activity operations $(r=0,4231 ; p<0,001)$.

\section{DISCUSSION}

The study results revealed that the basis for the formation of teachers' readiness for continuing education is a high level of development of meta-competence as a special property of their personality, reflecting their ability to independent cognitive activity.

In modern teaching, the traditional view is that the readiness for continuing education is formed based on positive inner motivation, so in practice, the focus is on the needs and motivations of teachers, ways to stimulate their desire for self-education and self-development ().

However, even with a high level of motivation, a mono-dimensional worldview, low intelligence, rigid thinking, and insufficient development of systemic thinking, analytical skills, and the ability to think deeply can block the mechanisms of inner development.

In this regard, it seems worthwhile to improve the process of forming future teachers' metacompetence as the basis for developing their readiness for continuing education. Such improvement can be carried out through the incorporation in the educational process of the university integrative technologies based on the main provisions of the meta-disciplinary approach and the idea of interdisciplinary relationships (Kremer \& Kuznetsova, 2017), which contribute to students' understanding of the universality of relations in the world (Mironova et al., 2019), students' awareness of the dialectics of the cognitive process, versatility, generality and the fundamentality of scientific concepts (Gurie et al., 2006). 
Therefore, integrative technologies are not only a necessary pedagogical condition for the development of meta-competence (Chetvertnykh, 2019), but also a factor that enhances the cognitive interest and activity of future teachers, integrating and systematizing all educational material, increasing its capacity, developing and activating professional thinking, strengthening its consistency, scale and, most importantly, independence, thereby stimulating the need and readiness of future teachers for continuous self-education and self-improvement.

\section{CONCLUSION}

The research results suggest that the formation of future teachers' readiness for continuing education should be based not only and not so much on stimulating their incentive activity but also on creating conditions for the development of their worldview, intelligence, systemic creative thinking, and general cognitive skills.

This condition is the integration of integrative technologies in the educational process of the university, which are based on interdisciplinary links and main provisions of the meta-disciplinary approach.

Authors' Contributions: All authors contributed equally.

Grebennikova, V. M.: conception and design, acquisition of data, analysis and interpretation of data, drafting the article, critical review of important intellectual content. Kazantseva, V. A.: conception and design, acquisition of data, analysis and interpretation of data, drafting the article, critical review of important intellectual content. Karpenko, A. N.: conception and design, acquisition of data, analysis and interpretation of data, drafting the article, critical review of important intellectual content. Krishtopa, A. N.: conception and design, acquisition of data, analysis and interpretation of data, drafting the article, critical review of important intellectual content. Us, O. A.: conception and design, acquisition of data, analysis and interpretation of data, drafting the article, critical review of important intellectual content. Tuzov, I. N.: conception and design, acquisition of data, analysis and interpretation of data, drafting the article, critical review of important intellectual content. All authors have read and approved the final version of the manuscript.

Ethics Approval: Not applicable.

Acknowledgments: Not applicable.

\section{REFERENCES}

Alekseeva, I. S. (2018). Modern challenges and professional development of a teacher. Bulletin of the North-Eastern Federal University named after V.I. M.K. Ammosov. Series "Pedagogy. Psychology. Philosophy", 2(10), 5-9.

Belkina, V. V., \& Makeeva, T. V. (2018). Concept of universal competences of higher education. Yaroslavl Pedagogical Bulletin, 5, 117-126.

Bonkalo, T. I., Logachev, N. V., \& Shmeleva, S. V. (2021). Formation of a professional and informational culture of future lawyers as a condition for solving the problems of digitalization of legal professions. In: Popkova, E. G., \& Sergi, B. S. (Eds.). Modern global economic system: evolutional development vs. revolutionary leap. ISC 2019. Lecture notes in networks and systems, vol. 198. Cham: Springer, pp. 1318-1327. https://doi.org/10.1007/978-3-030-69415-9 145

Chetvertnykh, T. V. (2019). Metasubject content of formative assessment. Bulletin of Kostroma State University. Series: Pedagogy. Psychology. Sociokinetics, 2, 21-25. https://doi.org/10.34216/2073-1426-2019-25-2-21-25

Fedotova, A. D., \& Starostina, S. E. (2018). Superdisciplinary modules as a means of forming universal competencies in masters according to updated educational standards. Scientific notes of the Trans-Baikal State University. Series: Pedagogical Sciences, 13(6), 118-128.

Grebennikova, V. M., \& Uzunova, G. P. (2020). Trends in the development of continuing professional education of teachers. Modern science-intensive technologies, 3, 133-137. https://doi.org/10.17513/snt.37954

Gurie, L. I., Kirsanov, A. A., Kondratyev, V. V., \& Yarmakeev, I. E. (2006). Integrative foundations of an innovative educational process in a higher professional school: monograph. Moscow: VINITI, $288 \mathrm{p}$.

Ivanova, E. O. (2018). Formation of universal competencies of students in the process of research activities. Yaros/avl Pedagogical Bulletin, 5, 146-155. 
Ivanova, I. V., Gutsu, E. G., \& Kochetova, E. V. (2015). Self-development of a teacher in the context of the implementation of a competence-based approach in education. Modern scientific research and innovations, 7-5(S1), 100-108.

Karpov, A. V., \& Demidova, P. G. (2013). On the content of the concept of personality metagognitive abilities. Proceedings of the DGPU, 4, 12-19.

Kazakova, E. I., \& Tarkhanova, I. Yu. (2018). On measuring the formation of universal competencies of university students. Pedagogy, 9, 79-83.

Kholodnaya, M. A. (2004). Cognitive styles. On the nature of the individual mind. 2nd ed. St. Petersburg: Peter, 384 p. Khutorskoy, A. V. (2013). Working with the metasubject component of the new educational standard. Public education, 4, 157-163.

Kremer, I. Yu., \& Kuznetsova, I. I. (2017). An integrative approach as the basis for the formation of a professionally competent personality of a future teacher. Bulletin of the Donetsk Pedagogical Institute, 3, 25-31.

Krishtopa, A. N. (2020). Model of development of meta competence in the process of natural science training of bachelors of pedagogy. Human capital, 3(135), 135-148.

Mironova, S. P., Olkhovskaya, E. B., \& Sapegina, T. A. (2019). Innovative technologies in professional training of bachelors: monograph. Yekaterinburg: Izdatel'stvo RGPPU, $171 \mathrm{p}$.

Osipov, M. V. (2019). The essence and structure of the meta competence of the subject of educational activity. Modern pedagogical education, 10, 12-14.

Penkova, I. V., Karpova, N. V., Shmeleva, S. V., \& Kartashev, V. P. (2018). Health disorders prevention in preschoolers by means of physical education: historical aspect. In: Ardashkin, I. B., Martyushev, N. V., Klyagin, S. V., Barkova, E. V., Massalimova, A. R., \& Syrov, V. N. (Eds.). The European proceedings of social and behavioural sciences. Future Academy, pp. 1042-1047.

Raspopova, E. A., Shmeleva, S. V., Tuzov, I. N., Sokolova, V. S., \& Latushkina, E. N. (2018). The issue of mental and motor disturbances and correction thereof in children with infantile cerebral paralysis and moderate mental retardation. Prensa Medica Argentina, 104(1), 1000272.

Ryzhov, B. N. (2010). Theory and methodology of systems psychology. Systemic foundations of psychology. Systemic psychology and sociology, 1(2). Available: http://www.systempsychology.ru/journal/2010_1_2/31-ryzhov-bnsistemnye-osnovaniya-psihologii.html

Shabanov, O. A. (2015). Meta-competence and meta-competence in the framework of the competence-based approach in education. Man and education, 3(44), 53-56.

Strelkov, V. I., Zavarzina, O. O., Shmeleva, S. V., Kartashev, V. P., \& Savchenko, D. V. (2016). Psychological barriers in college teacheres "helping professions". Research Journal of Pharmaceutical, Biological and Chemical Sciences, 7(1), 1938-1945.

Sychev, I. A. (2009). Pedagogical conditions for the formation of elements of systems thinking in senior students. Dissertation for the degree of pedagogical sciences. Altai State Pedagogical Academy, Barnaul, 197 p.

Tarkhanova, I. Yu. (Ed.). (2018). Measurement and assessment of the formation of universal competencies of students in the development of educational programs for bachelor's, master's, specialty: collective monograph. Yaroslavl: RIO YAGPU, $383 \mathrm{p}$.

Tarkhanova, I. Yu. (2019). Formation of universal competencies of university students by means of educational and industrial practice. Socio-political research, 1, 110-118. https://doi.org/10.24411/2658-428X-2019-10344

Received: 31 June 2021 | Accepted: 22 September 2021 | Published: 16 October 2021 